\title{
TINJAUAN KRIMINOLOGI TERHADAP PENYALAHGUNAAN NARKOBA BAGI REMAJA DI WILAYAH KABUPATEN REMBANG
}

\author{
Siti Rosedevio T, Safik Faozi
}

Fakultas Hukum, Universitas Stikubank (UNISBANK) Semarang

E-mail : s.rosedevio5758@gmail.com, safikfaozi@edu.unisbank.ac.id

\begin{abstract}
ABSTRAK
Penyalahgunaan narkoba yang dilakukan remaja merupakan suatu permasalahan yang sangat serius. Karena remaja merupakan calon generasi penerus bangsa. Remaja merupakan pilar dari kekuatan sosial yang sangat berperan dalam pembangunan suatu bangsa dan negara. Dalam kurun waktu dekade terakhir permaslahan ini menjadi marak. Terbukti dengan bertambahnya jumlah penyalahgunaan atau pecandu narkoba secara signifikan, hal ini membuat penulis ingin mengetahui Faktor yang menyebabkan terjadinya tindak pidana penyalahgunaan narkoba oleh remaja di Kabupaten Rembang dan upaya yang dilakukan oleh pihak Kepolisian Resor Rembang dalam menanggulangi terjadinya tindak pidana penyalahgunaan narkoba oleh remaja di Kabupaten Rembang. Hal tersebut menarik bagi penulis untuk membuat karya ilmiah mengenai tinjauan kriminologi terhadap penyalahgunaan narkoba bagi remaja di wilayah kabupaten rembang.

Metode yang digunakan oleh penulis adalah yuridis sosiologis yaitu dengan cara wawancara maupun pengumpulan data baik dari data primer maupun sekunder. Menurut hasil penelitian bahwa Faktor yang paling utama mempengaruhi penyalahgunaan adalah faktor lingkungan dan didikan orang tua. Dalam kehidupan sehari-hari masih banyak dijumpai remaja yang melakukan penyalahgunaan dan polres Rembang dalam menanggulanginya melakukan beberapa hal, yaitu Upaya Represif dalam Bentuk Koodinasi Terbuka dan Upaya Represif dalam Bentuk Koodinasi Tertutup.
\end{abstract}

Kata kunci : Penyalahgunaan, Remaja, Narkoba 


\begin{abstract}
Drug abuse by teenagers is a very serious problem. Because adolescents are candidates for the nation's next generation. Youth is a pillar of social strength which plays a very important role in the development of a nation and country. In the past decade, this problem has become rampant. Evidenced by the significant increase in the number of searchers or drug addicts, this makes me see the factors that cause drug crime by adolescents in Rembang Regency and the efforts made by the Rembang Resort Police in overcoming drug crimes by teenagers in Rembang Regency. This is interesting for the author to make a scientific paper on the criminological review of drugs for adolescents in the Rembang district.

The method used by the author is sociological juridical, namely interviews and data interviews, both primary and secondary. According to the results of the study, the factors that most influence decisions are environmental factors and parental education. In daily life, there are still many adolescents who carry out abolition and the Rembang police in overcoming it have done several things, namely repressive efforts in the form of open coordination and repressive efforts in the form of closed coordination.
\end{abstract}

Keywords: Abuse, Teenagers, Drugs 


\section{PENDAHULUAN}

Remaja merupakan pilar dari kekuatan sosial yangj sangat berperan dalam pembangunan suatu bangsa dan negara. Remaja adalahgenerasi penerus perjuangan bangsa Indonesia yangj mempunyai hak dan kewajiban ikut serta dalam membangun negara dan bangsa Indonesia. Generasi muda dalam hal ini remaja merupakan subyek dan obyek langsung pembangunan nasional dalam usaha mencapai tujuan bangsa Indonesia untuk mewujudkan masyarakat yang adil dan makmur sesuai dengan Pancasila dan UUD 1945. Remaja merupakan pilar penting yang akan menentukan nasib peradaban masyarakat di masa yang akan datang. Remaja mempunyai ciri dan sifat khusus yang memerlukan pembinaan dalam rangka menjamin pertumbuhan fisik dan mentalnya secara utuh, selaras dan seimbang.

Permasalahan serius yang sedang dihadapi bangsa Indonesia adalah masalah kenakalan remaja yang juga persoalan aktual di hampir setiap negara di dunia. Sebagai gambaran obyektif adalah merebaknya kasus-kasus pelanggaran hukum yang dilakukan remaja berupa perkelahian, penodongan, perampokan, pencurian, pemilikan senjata tajam bahkan penyalahgunaan narkoba atau berbagai pelanggaran hukum lainnya.

Remaja adalah modal dan aset pembangunan yang akan memelihara dan mengembangkan hasil pembangunan secara fisik atau mental sosial Indonesia yang harus ditumbuhkembangkan sebagai manusia seutuhnya,sehingga mempunyai kemampuan untuk melaksanakan hak dan kewajibannya sebagai warga negara Indonesia yang senantiasa memiliki tanggungjawab dan bermanfaat sesuai dengan Pancasila dan UUD 1945.

Upaya pemberantasan narkoba sudah sering dilakukan,namun masih sedikit kemungkinan untuk menghindarkan narkoba dari kalangan remaja maupun dewasa. Hingga saat ini upaya yang paling efektif untuk mencegah pengaruh narkoba pada remaja yaitu dari pendidikan,keluarga.

Orang tua diharapkan mengawasi dan mendidik anaknya untuk selalu menjauhi narkoba. Dan hingga kini narkoba pun telah merajalela di kalangan siswa-siswa SMP maupun SMA. Hal tersebut akan mengganggu prestasi belajar siswa yang mengkonsumsi narkoba tersebut. Jika remaja pengguna telah mencapai fase ketagihan, akan merusak jaringan ditubuh pengguna yang mengakibatkan penurunan tingkat konsentrasi dalam pelajaran, selalu gelisah, tidak fokus di sekolah sehingga prestasi siswa pecandu akan menurun.

Penyalahgunaan dalam penggunaan narkoba adalah pemakaian obat-obatan atau zat-zat berbahaya. Beberapa penyebab umum terjadinya masalah penyalahgunaan narkoba oleh remaja adalah adanya anggapan bahwa memakai narkoba adalah salah satu gaya hidup di zaman sekarang selain ketidaktahuan atau minimnya pengetahuan remajaakan berbahayanya penyalahgunaan narkoba. Keinginan besar besar mencoba tanpa mengetahui akibatnya di masa mendatang juga menjadi salah satu penyebab penyalahgunaan narkoba oleh remaja.

Faktor lingkungan sekitar dan keluarga juga berpengaruh dalam 
penyalahgunaan narkoba oleh remaja. Adanya faktor kurang kasih sayang, perhatian juga keutuhan keluarga berpengaruh sangat besar dalam hal ini. Faktor lingkungan atau komunitas juga berpengaruh besar, karena merasa dalam lingkungan keluarga kurang mendapatkan perhatian, maka mencari perhatian diluar dan mendapatkan lingkungan atau komunitas yang kurang tepat.

Berkaitan dengan masalah penyalahgunaan narkotika (sering disebut narkoba pada saat ini) oleh remaja, merupakan salah satu masalah yang sangat kompleks yang memerlukanj upaya penanggulangan yang komprehensif dengan melibatkan kerjasama antara multidispliner, multi sektor dan peran serta masyarakat secara aktif yang dilaksanakan secara berkesinambungan, konsekuen dan konsisten.

Perkembangan penyalahgunaan narkoba oleh dari waktu ke waktu menunjukan kecenderungan semakin meningkat dan akan berakibat sangat merugikan bagi individu maupun masyarakat luas dan terhadap remaja. Khususnya terhadap remaja yang sedang berada dalam fase transisi perkembangan antara masa anak-anakdan masa dewasa yang dapat menimbulkan masa krisis, ditandai dengan kecenderungan munculnya perilaku menyimpang dimana pada masa remaja akan timbul keinginan yang tinggi untuk mencoba-coba sesuatu, mengikuti tren dan gaya hidup,bersenang-senang walaupun semua kecenderungan tersebut adalah wajar,tetapi hal itu bisa juga memudahkan remaja untuk terdorong untuk menyalahgunakan narkoba. Oleh karena itulah apabila pada masa remaja telah rusak karena narkoba, maka hampir pasti suram atau hancur masa depan remaja tersebut.

Peran Pemerintah Daerah Kabupaten Rembang sangatlah besar dalam pencegahan penyalahgunaan narkoba. Sampai tahun 2017 tercatat capaian Pemda Rembang mencapai 98,40 \% dari $100 \%$ Prestasi Kinerja dan anggaran Kegiatan Urusan Pemuda Dan Olah Raga dan menghabiskan dana 165.000 .000 juta rupiah dalam Program Pencegahan Narkoba di Triwulan ke empat ${ }^{1}$. Hal tersebut membuktikan bahwa Pemda Rembang sangat berkomitmen dalam pencegahan penyalahgunaan narkoba di wilayahnya.

Fenomena yang terjadi di wilayah hukum Kabupaten Rembang berkaitan erat dengan era globalisasi dan kecepatan informasi yang secara signifikan berpengaruh terhadap pola pemikiran remaja, diantaranya pergeseran pola pikir dan pergaulan di masyarakat. Pergeseran pola pikir yang dimaksud sebagai contoh adalah remaja yang beberapa waktu lalu sebagian besar pada sore hari beraktivitas di lingkungan keluarga dan sekitarnya sedikit banyak beralih ke gawai untuk beraktivitas di sosial media sehingga kemajuan globalisasi mengakibatkan kurangnya fungsi kontrol keluarga dan diri pribadi remaja yang disebabkan oleh banyaknya informasi yang diterima remaja tidak tersaring dengan benar.

Usaha untuk mencapai tingkat kesad aran hukum di kalangan remaja dapat di lakukanmelalui beberapa aktivitas,akan te tapi yang paling sederhana dan terakrab dengan kehidupan remaja adalah melalui

\footnotetext{
${ }^{1}$ RKPD Kabupaten Rembang 2012
} 
penyuluhan hukum yang dapat divisualisasikan dalam beragam bentuk dan jenisnya ${ }^{2}$.

Kabupaten Rembang yang merupakan wilayah hukum Polres Rembang dengan peningkatan jumlah populasi penduduk yang cukup tinggi setiap tahunnya serta berada pada lokasi yang strategis yaitu merupakan salah satu jalur akses transportasi Pantai Utara Jawa Tengah dan juga menjadi pusat aktivitasperekonomian, perdagangan serta kegiatan masyarakat lainnya sehingga memungkinkan akan banyak terjadi tindak pidana di tengah-tengah kehidupan masyarakat khususnya tindak pidana penyalahgunaan narkoba yang melibatkan remaja sebagai pelaku tindak pidana.

\section{Rumusan Masalah}

Dari uraian yang dikemukakan dalam latar belakang masalah di atas, maka dapat dirumuskan beberapa permasalahan sebagai berikut :

1. Faktor-faktor apakah yang menyebabkan terjadinya tindak pidana penyalahgunaan narkoba oleh remaja di Kabupaten Rembang?

2. Bagaimanakah upaya-upaya yang dilakukan oleh pihak Kepolisian Resor Rembang dalam menanggulangi terjadin ya tindak pidana penyalahguna an narkoba oleh remaja di Kabupaten Rembang?

\section{METODE PENELITIAN}

Penelitian yang penulis gunakan adalah jenis penelitian yuridis sosiologis. Jenis penelitian yuridis sosiologis

${ }^{2}$ Sudarsono. Kenakalan Remaja. Jakarta.Rineka Cipta 2012. H.5 merupakan penelitian hukum yang menggunakan data primer atau data lapangan, meneliti efektivitas suatu undangundang dan penelitian yang ingin mencari hubungan (korelasi) antara berbagai gejala atau variabel sebagai alat pengumpul datanya terdiri dari studi dokumen, pengamatan (observasi), dan wawancara (interview). Kegunaan penelitian hukum sosiologis adalah untuk mengetahui bagaimana hukum itu dilaksanakan termasuk proses penegakan hukum (law enforcement), karena penelitian jenis ini dapat mengungkapkan permasalahanpermasalahan yang ada dibalik pelaksanaan dan penegakan hukum ${ }^{3}$.

Metode penelitian hukum empiris adalah suatu metode penelitian hukum yang berfungsi untuk melihat hukum dalam artian nyata dan meneliti bagaimana bekerjanya hukum di lingkungan masyarakat. Dikarenakan dalam penelitian ini meneliti orang dalam hubungan hidup di masyarakat maka metode penelitian hukum empiris dapat dikatakan sebagai penelitian hukum sosiologis. Dapat dikatakan bahwa penelitian hukum yang diambil dari faktafakta yang ada di dalam suatu masyarakat, badan hukum atau badan pemerintah ${ }^{4}$. Penelitian ini bertujuan memberikan gambaran secara rinci, sistematis dan menyeluruh mengenai segala sesuatu yang berkaitan dengan penyalahgunaan narkoba oleh remaja. Menggunakan data primer (data

3 Ronny Hanitjo Soemitro, Metodologi Penelitian Hukum, Ghalia: Jakarta, 1998, Hlm. 34

4 Arikunto, Suharsimi. Manajemen Penelitian. Jakarta: Rineka Cipta. 2005. 
yang diperoleh langsung dari kehidupan masyarakat dengan cara wawancara, observasi, kuesioner, sample dan lain- lain)

\section{PEMBAHASAN}

\section{Faktor-Faktor Penyalahgunaan Narkoba}

Penyalahgunaan narkoba adalah penggunaan narkoba yang bukan untuk tujuan pengobatan, tetapi agar dapat menikmati pengaruhnya, dalam jumlah berlebih, secara kurang lebih teratur, berlangsung cukup lama, sehingga menyebabkan ganggunan kesehatan fisik, gangguan kesehatan jiwa, dan kehidupan sosialnya. Penyalahgunaan narkoba oleh remaja merupakan masalah yangserius, karena penyalahgunaan narkoba dapat merusak masa depan remaja.

Berikut adalah faktor-faktor penyebab seseorang menjadi penyalahguna narkoba:

(1) Penyebab dari diri sendiri yaitu ketidakmampuan menyesuaikan diri dengan lingkungan kepribadian yang lemah, kurangnya percaya diri, tidak mampu mengendalikan diri dari dorongan ingin tahu, ingin mencoba, ingin meniru, dorongan ingin berpetualang. Dapat mengalami tekanan jiwa dan tidak memikirkan akibatnya dikemudian hari akan bahaya narkoba.

(2) Penyebab yangj bersumber dari keluarga (orang tua) Salah satu atau kedua orang tua adalah pengguna narkoba tidak mendapatkan perhatian dan kasih sayang dari orang tua, keluarga kurang harmoni, komunikasi yang kurang terbuka dalam keluarga. Orang tua tidak memberikan pengawasan kepada anaknya karena terlalu sibuk mencari uang/mengejar karir sehingga perhatian kepada anaknya menjadi terabaikan

(3) Penyebab dari teman/kelompok sebaya adalah adanya satu atau beberapa teman kelompok yang menjadi pengguna narkoba maupun pengedar narkoba. Serta adanya ajakan atau rayuan dari teman kelompok untuk menggunakan narkoba secara paksa karena apabila tidak mau menggunakan akan dianggap tidak setia kawan.

(4) Penyebab yang bersumber dari lingkungan adalah masyarakat tidak acuh atau tidak peduli dengan masyarakat lainnya, dikarenakan sudah terbiasa dengan lingkungan yang seperti itu. Sehingga banyaknya pengedar narkoba yang mencari konsumen disekitar tempat tinggal tidak terjamah oleh pihak berwajib karena hukum yang masih lemah.

\section{Upaya-Upaya yang dilakukan Polres Rembang}

Hasil wawancara yang dilakukan peneliti pada tanggal 20 November 2019 di Kepolisian Resort Rembang terhadap Kepala Seksi Pemberdayaan Masyarakat Kepolisian Resort Rembang Kota Rembang yaitu AKP Bambang Sugito menyatakan bahwa adanya korban penyalahgunaan narkotika oleh anak seharusnya dilindungi oleh pihak manapun yaitu Orang tua korban tersebut atau pihak Kepolisian Resort Rembang yang ada dimana pun baik di Kota Rembang maupun di Kota manapun karena anak merupakan kelompok sangat rentan 
dengan perkembangan emosional anak tersebut sehingga masih belum stabil. Ketika anak tersebut menjadi korban penyalahgunaan narkotika maka tindakan yang yang dilakukan oleh orang tua tersebut harus melaporkan ke pihak Kepolisian Resort Rembang guna untuk mendapatkan perlindungan dibidang kesehatan, maupun psikologis anak tersebut agar anak tersebut bisa melanjutkan masa depan dengan baik sebagai generasi bangsa kedepan.

Oleh karena itu untuk melindungi anak yang menjadi korban pecandu narkotika, orang tua atau wali dari anak yang menjadi korban pecandu narkotika berkewajiban melaporkan kepada pejabat yang ditunjuk oleh pemerintah untuk mendapatkan pengobatan dan perawatan. Ketentuan tersebut terdapat dalam Pasal 55 UndangUndang No.35 Tahun 2009 Tentang Narkotika, yaitu yang berbunyi sebagai berikut :

(1) Orang tua atau wali dari Pecandu Narkotika yangj belum cukup umur wajib melaporkan kepada pusat kesehatan masyarakat, rumah sakit, dan/atau lembaga rehabilitasi medis dan rehabilitasi sosial yang ditunjuk oleh Pemerintah untuk mendapatkan pengobatan dan/atau perawatan melalui rehabilitasi medis dan rehabilitasi sosial.

(2) Pecandu Narkotika yang sudah cukup umur wajib melaporkan diri atau dilaporkan oleh keluarganya kepada pusat kesehatan masyarakat, rumah sakit, dan/atau lembaga rehabilitasi medis dan rehabilitasi sosial yang ditunjuk oleh Pemerintah untuk mendapatkan pengobatan dan/atau perawatan melalui rehabilitasi medis dan rehabilitasi sosial. Pengobatan dan perawatan terhadap pecandu narkotikaj dilakukan melalui fasilitas rehabilitasi. Rehabilitasi bagi pecandu narkotika dilakukan, dengan maksud untuk memulihkan dan mengembangkan kemampuan fisik, mental dan sosial penderita yangj bersangkutan.

Ada 2 (dua) macam rehabilitasi yang dimaksud, yaitu rehabilitasi medis dan rehabilitasi sosial :

(1) Rehabilitasi medis Pecandu Narkotika dilakukan dirumah sakit yang ditunjuk oleh Menteri.

(2) Lembaga rehabilitasi tertentu yang diselenggarakan oleh instansi pemerintah atau masyarakat dapat melakukan rehabilitasi medis Pecandu Narkotika setelah mendapat persetujuan Menteri. Selain undangundang Nomor 35 Tahun 2009 Tentang Narkotika yang mengatur tentang narkotika ada pula regulasi lain yang mengatur tentang korban narkotika yaitu peraturan bersama yang diterbitkan oleh Ketua Mahkamah Agung Republik Indonesia, Menteri Hukum Dan Hak Asasi Manusia Republik Indonesia, Menteri Kesehatan Republik, Menteri Sosial Republik Indonesia, Jaksa Agung Republik Indonesia, Kepala Kepolisian Negara Republik Indonesia, Kepala Badan Narkotika Nasional Republik Indonesia, tentang penanganan pecandu narkotika dan korban penyalahgunaan narkotika ke dalam lembaga rehabilitasi, dalam peraturan tersebut telah ditentukan 
bahwa lembaga rehabilitasi korban penyalahgun aan narkotika adalah rehabilitasi medis dan rehabilitasi social. Rehabilitasi Medis adalah suatu proses kegiatan pengobatan secara terpadu untuk membebaskan pecandu dari ketergantungan

\section{PENUTUP}

Simpulan

Berdasarkan uraian di atas, maka penulis dapat menarik kesimpulan sebagai berikut :

Secara garis besar faktor yang menyebabkan terjadinya penyalahgunaan narkoba di kalangan remaja terdiri dari faktor internal maupun faktor eksternal. Faktor internal, yakni faktor yang berasal dari diri seseorang, dimana faktor internal itu sendiri terdiri dari : Faktor Kepribadian, Faktor Keluarga serta Faktor Ekonomi. Selanjutnya Faktor Eksternal, yakni faktor yang berasal dari luar seseorang / remaja yang mempengaruhi terjadinya penyalahgunaan narkoba.

Adapun Faktor Eksternal itu sendiri terdiri dari : Faktor Pergaulan Dan Faktor Sosial/ Masyarakat. Dari beberapa faktor tersebut yang terlihat paling dominan yang menyebabkan terjadinya penyalahgunaan narkoba di kalangan remaja adalah disebabkan karena faktor pergaulan dan lingkungan, dimana karena pergaulan yang terlalu bebas dan tidak terkontrol menyebabkan remaja hilang kendali sehingga mudah terpengaruh dengan mengkonsumsi narkoba. Selain itu kondisi kepribadian remaja yang tergolong masih labil sehingga remaja mudah terbujuk untuk menyalahgunakan narkoba tanpa memikirkan dampak buruk dari narkoba itu sendiri.

Selain dari faktor pergaulan ada faktor lingkungan sekitar yang mendukung, yang memiliki arti dimana masyarakat tidak memperhatikan atau bahkan tidak menegur dengan adanya penggunaa narkoba di lingkungan tersebut, diakrenakan sudah menjadi ciri khas dari lingkungan tersebut yang terkenal dengan adanya tindak kriminal.

Dengan adanya peningkatan pengguna narkoba tersebut, polres Rembang dalam menanggulanginya melakukan beberapa hal, yaitu : Upaya Represif dalam Bentuk Koodinasi Terbuka dan Upaya Represif dalam Bentuk Koodinasi Tertutup. Upaya Represif dalam Bentuk Koodinasi terbuka ini dilakukan pihak Polres Kepolisian Resort Rembang Kota yang dimandatkan dari Kapolres pada SatReskoba yang diwakili oleh Kasat Reskoba, berkoordinasi dengan Kalapas yangj bersangkutan dengan narapidana warga binaan yang mendekam didalam Lapas tersebut.

Sedangkan upaya Represif dalam Bentuk Koodinasi Tertutup, Tertutup berarti koordinasi ini hanya dilakukan olehj pihak Kepolisian saja untuk mengungkap kasus adanya peredaran narkoba entah itu peredaran narkoba yang terjadi didalam Lapas atau pengendalian peredaran narkoba yang dilakukan dari dalam Lapas keluar area Lapas pada masyarakat pada umumnya. Selain melakukan upaya tersebut, pihak kepolisian juga melakukan rehabilitasi untuk memulihkan mental para pengguna. 
Saran

Diharapkan peran orang tua untuk lebih mengawasi dan membimbing anggota keluarganya, serta lebih meluangkan waktunya untuk selalu berada disisi anak anaknya dalam kondisi apapun, sehingga remaja tidak terjerumus melakukan hal yang menyimpang terutama melakukan penyalahgunaan narkoba. Masyarakat hendaknya melakukan kegiatan yang positif dan berguna agar remaja tidak terlibat dalam kasus penyalahgunaan narkoba serta memperdalam iman dan taqwa guna ketahanan diri dalam menghadapi dan memecahkan permasalahan hidup.

Diharapkan pihak BNN lebih meningkatkan pengawasan dan menindak tegas para pelaku kejahatan narkoba yang dapat merusak generasi bangsa, serta lebih meningkatkan pemahaman-pemahaman kepada masyarakat akan bahaya penyalahgunaan narkoba

\section{DAFTAR PUSTAKA}

\section{Literatur :}

Abdussalam, H. R. (2007). Kriminologi. Jakarta: Restu Agung.

Alifia, U. (2008). Apa itu Narkotika dan Napza. Semarang: PT.Bengawan Ilmu.

Amiruddin. (2006). Pengantar Metode Penelitian Hukum. Dalam Amiruddin, Pengantar Metode Penelitian Hukum (hal. 30). Jakarta: PT Raja Grafindo.

Anang, P. (2012). Kriminologi. Dalam P. Anang, Kriminologi (hal. 19). Yogyakarta: Penerbit Ombak.

Andi, \& Hamzah. (2009). Delik-Delik Tertentu (Speciale Delicten di dalam KUHP. Dalam Andi, \& Hamzah, DelikDelik Tertentu (Speciale Delicten di dalam KUHP (hal. 224). Jakarta: Sinar Grafika.

Arikunto, \& Suharsimi. (2005). Manajemen Penelitian . Jakarta: Rineka Cipta.

Budianto. (1989). Narkoba dan Pengaruhnya. Bandung: Ganeca Exact.

E, Y. K., \& S, R. S. (2002). Asas-Asas Hukum Pidana di Indonesia dan Penerapannya . Jakarta: Storia Grafika.

Hari, Sasangka, \& Lili, R. (2003). Hukum Pembuktian dalam Perkara Pidana. Dalam Hari, Sasangka, \& R. Lili, Hukum Pembuktian dalam Perkara Pidana (hal. 35). Bandung: Mandar Maju.

Indah, S. U. (2012). Aliran dan teori Dalam Kriminologi. Dalam S. U. Indah, Aliran dan teori Dalam Kriminologi (hal. 48). Yogyakarta: Thafa Media.

M, W. (1999). Narkotika, Psikotropika dan Obat Berbahaya. Jakarta: YAyasan Mitra Bintibmas.

Ninik, W., \& Yulius, W. (1987). Kejahatan dalam masyarakat dan pencegahannya. Dalam W. Ninik, \&

W. Yulius, Kejahatan dalam masyarakat dan pencegahannya (hal. 54). Jakarta: Bima Aksara.

Ronny , H. S. (1998). Metodologi Penelitian Hukum. Dalam H. S. Ronny, Metodologi Penelitian Hukum (hal. 34). Jakarta: Ghalia.

Rusli, \& Efendi. (1986). Masalah Kriminalisasi dan Dekriminalisasi dalam Rangka Pembaruan Hukum Nasional"dalam BPHN. Jakarta: Binacipta.

Sani, \& Abdullah. (t.thn.). Hakim dan Keadilan Hukum. Dalam Sani, \& Abdullah, Hakim dan Keadilan Hukum (hal. 15). Jakarta: Bulan Bintang. 
Sarjono , S. (1983). pengantar Penelitian Hukum. Jakarta: Univrsitas Indonesia Press.

Soesilo, R. (1985). Kriminologi (Pengetahuan Tentang Sebab-Sebab Kejahatan). Bogor: Politeia.

Jurnal / Disertasi :

Sri, P. (2001). Penyalahgunaan Narkoba di Indonesia. 12. Dipetik 11 2019, dari http://doi.org/10.22146/jp.12275

Hasanudin. (2009). Pelayanan Kepada Narapidana Narkoba dalam

Penyelenggaraan Sistem Permasyarakatan: Studi Kasus pada Lembaga permasyarakatan Narkotika Jakarta. Bandung : Disertasi Doktor pada Program Pascasarjana UNPAD.

Hermanto. (2009). Manajemen Layanan Rehabilitasi Korban Penyalahgunaan Narkoba di Panti Sosial Pamardi Putra "Sehat Mandiri, Yogyakarta". Yogyakarta : Disertasi Doktor pada Sekolah Pascasarjana UGM.

\section{Undang-Undang}

Undang-Undang Nomor 35 Tahun 2009 tentang Narkotika

Undang-Undang Republik Indonesia No. 5 tahun 1997 tentang Psikotropika

Undang-Undang Sistem Peradilan Pidana Anak 